\title{
A Review of Literature on Information Management utilizing ICT in Higher Education Mr. Vikram Sharma
}

\author{
Vikram Sharma \\ D.M. College of Education, Moga (Punjab), India \\ Email: vkrmsharma@ymail.com
}

\begin{abstract}
The paper plans to study the job of Information Management (IM) utilizing Information and Communication Technology (ICT) in advanced education by leading writing survey and arrangement of articles from 2000 to 2012 so as to investigate how IM advances and applications have been created right now. The development of Information and Communication Technologies (ICT) in the most recent decade has opened new roads in Information Management that could assume significant jobs in meeting the overall provokes identified with sharing, trading and scattering information and advances in the advanced education. This paper gives an elevated level diagram of IM utilizing Information and Communication Technology (ICT) in advanced education. A basic examination is finished by considering endeavors made by experts to actualize IM utilizing ICT in advanced education.
\end{abstract}

Keywords: information management, ICT, higher education, knowledge.

\section{Introduction}

Information is a limit of individuals and networks to constantly produce and reestablish themselves to address new difficulties and openings. The development of the propelled administration part and the expanding need of unimportant work, have contributed drastically to change the manner by which information is created, dispersed and expended. Information is a dynamic and smooth progression of particular encounters, qualities and bits of knowledge. Various individuals, seeing the benefit of estimating scholarly resources, perceived the developing significance of authoritative information as a serious resource. Colleges and other advanced education foundations are associated with information creation, scattering and adapting subsequently they are perceived to be in the information business.

Information Management (IM) idea is presented in the start of 1990. Information the executives is worried about the misuse and improvement of the information resources of an association with the end goal of assisting the association's targets (Rowley 2000). IM is a methodical, composed, and unequivocal and consider progressing procedure of making, dispersing, applying, restoring and refreshing the information for accomplishing hierarchical objectives (Elias and Hassan 2004). Information the executive is worried about the abuse and improvement of the information resources of an association with the end goal of advancing the association's destinations. The information to be overseen incorporates both express,

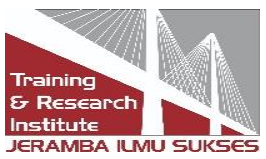


International Journal of information Systems and Informatics

p-ISSN $x x x x-x x x x$, e-ISSN: $x x x x-x x x x$

Vol. 1, No.1, September 2020

reported information, and unsaid, abstract information. The board involves those procedures related with the distinguishing proof, sharing and formation of information. This requires frameworks for the creation and upkeep of information stores, and to develop and encourage the sharing of information and hierarchical learning (Davenport and Prusak 1998). IM has three essential components for example age of new information, scattering of the information and utilization of the information. Hierarchical culture, mechanical instruments and individuals are the key components required for overseeing information all the more successfully for better instruction conveyance in time staged way, (Petrides and Nodine 2003). With IM advanced education organizations are better ready to expand understudy maintenance and better alumni rates, work to break down the practical utilization of innovation to meet greater enrolment, change existing exchange based framework to give data and contend in a situation where establishments cross state and national fringes to address understudy issues whenever/anyplace.

There have been numerous advanced education Institutions that have actualized IM standards, strategies, practices or devices. This paper gives a significant level of outline and endeavors made by advanced education foundations about execution of IM utilizing ICT. The remainder of the paper is sorted out into four segments. In the primary area, outline is given about the related work acted in advanced education identified with IM utilizing ICT, followed with the unthinkable portrayal of various ICT apparatuses and application region is talked about. Further discoveries and recommendations are given and afterward paper is finished up.

\section{Literature Review}

ICT is a group of felt that attention on how data is overseen. A wide scope of ICT apparatuses is utilized to make, systematize and share information over both geological and transient limits. Right now area an endeavor is made to direct survey of writing identified with usage of IM utilizing ICT in advanced education and afterward basic examination is done.

Jennifer Rowley (2000) made an investigation on usage of IM in advanced education in Joined Kingdom and announced that the current offices like libraries, electronic assortments of learning materials, systems for email correspondence, and the board data framework give information on the understudy profile. With the help of JANET organize analysts and scholastic staff approach electronic reports, email, access to organize assets, preparing and mindfulness and so on. (Kidwell, Vander Linde et al. 2000) focused on the significance of IM methods and advancements in advanced education which helps for dynamic capacities, decreased item advancement cycle time for example educational plan advancement and research, improved scholarly and regulatory administrations and decreased expenses. $\mathrm{He}$ recommended to configuration online gateway to offer the administrations, for example, investigate subtleties, educational plan improvement and its modification, workforce improvement programs, understudy administrations, profession arrangement

Published

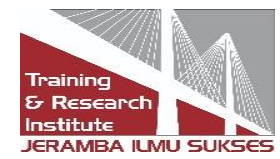


International Journal of information Systems and Informatics

p-ISSN $x x x x-x x x x$, e-ISSN: $x x x x-x x x x$

Vol. 1, No.1, September 2020

administrations, graduated class affiliation administrations, for bookkeeping area and HR subtleties. (Khare, Saxena et al. 2003) declared the use of IM advances in various regions like investigation material improvement information, understudy enrollment information, bolster administrations information, study material creation and appropriation information and assessment and accreditation information for separation instruction courses in IGNOU. Through the work (Milam Jr 2001) stresses the utilization of IM in higher instruction with the assistance of web-based interface which is utilized seriously for group coordinated effort and groupware, characteristic language questions of information, sharing data on best practices and whenever/anyplace on the web learning. For sharing and appropriating information in the association, innovations proposed are information stockrooms, information mining, and computer generated reality demonstrating to imagine and rise above exceptionally complex, exchange based information. (Renner 2004) investigated the significance of ICT to make what's more, share top notch sight and sound substance through online information sharing framework by creating Kshare framework for shared learning among instructors and understudies through intranet inside the foundation to gain, use and offer information by utilizing ICT.

A proper way to deal with the utilization of web journals as learning spaces in the advanced education segment has been proposed by (Williams and Jacobs 2004) by directing an overview about the use of Blogs in Harvard Law School, the Brisbane Graduate School of Business (BGSB) at Queensland University of Technology (QUT).In the paper, The Implementation of Information Management System In Taiwan's Higher Education, (Yeh 2005) states the use of information the executives frameworks in a private school in Taiwan, which is confronting managerial difficulties and bleeding edge rivalry. A total specialized and authoritative foundation is worked by re-appropriating customized Gweb e-IM arrangement programming on Lotus Domino System by making a culture of information sharing utilizing association wide jargon.

(Oliveira, Souza et al. 2005) has proposed GCC - A domain for information the executives in Scientific Research and Higher Education Centers. (Jones, Provost et al. 2006) illuminates improvement of an online interface to associate analysts in college to fill an apparent hole in information sharing and openness inside the University utilizing information the executive's strategies. Web-based interface encourage information securing, sharing and disclosure by permitting individuals to distribute archives, share thoughts, work cooperatively and store data and information in effectively accessible vaults. (Jones, Provost et al. 2006) in his investigation on IM way to deal with creating networks of training among college and school staff recommended to set up Higher Education Learning Partnerships Center for Excellence in Teaching and Learning (HELP CETL) to help staff engaged with the conveyance of advanced education level from establishment degrees through a system of nineteen further instruction universities. To accomplish this, an IM framework utilizing a Community of

Published

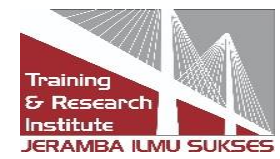


International Journal of information Systems and Informatics

p-ISSN $x x x x-x x x x$, e-ISSN: $x x x x-x x x x$

Vol. 1, No.1, September 2020

Practice $(\mathrm{CoP})$ Framework was examined and afterward utilized as the key HELP CETL correspondence and data sharing instrument.(Thitithananon, Klaewthanong et al. 2007) investigates a usage of IM rehearses in Thailand's Higher Education improvement by utilizing ICT instruments for improving the present instruction frameworks so as to be concurrence with the regal declaration of rules and guidelines in greatness of nation the board . (Sharma, Saini et al. 2007) arranged a product instrument EDULOGIC for building organizations for granting quality instruction in a profoundly organized, controlled and evaluated way. The information, substance and results created over coterminous years fabricate the essential ground for dealing with the related aggregated information for understudies and workforce. (Abdullah, Shahabudin et al. 2007) talked about the job of KMS to serve staff networks in higher learning establishments to advance information sharing, stockpiling and catch and speak to the information. Creator has further arranged a model of groupware assistance for information partaking in higher learning establishments by utilizing K Portal, database server.

(Aharony 2008) made an examination on the utilization of Wiki in a Information Management Academic Course to help conversation during the way toward making and sharing information, for the conveyance of class educational plan and extends and to empower understudies and educators to be in a nonstop conversation, which can be utilized as an information vault. The exploration is centered on including wiki pages which were accumulated from information the executive's wiki course in Israel and plans to investigate and break down the application and utilization of a wiki, a key idea of Web 2.0, in information the board scholastic course. (Meena Kharatmal and Nagarjuna 2005) has expressed the target of GNOWSYS for overseeing library, information the board, Information gateways (portals) and conveyed semantic matrix for distributing information. Utilizing GNOWSYS it is conceivable to create semantic system, idea charts and circle outlines .(Nyame-Asiamah 2009) has expressed to look at the commitments and reasonableness of the accessible information the board (IM) advances, including the Web 2.0 for misusing implicit information. It proposes a coordinated system for removing implicit information in associations, which incorporates Web 2.0 advancements, IM instruments, authoritative learning (OL) and Community of Practice (CoP).

(Bebensee, Helms et al. 2010) investigated the Web 2.0 applications as methods for supporting up IM by directing examination in Germany by utilizing free Web 2.0 devices for working together and sharing documents with one another among understudies. (Mansourvar and Yasin 2010) has expressed that web-based interface as the kind of information the board framework gives a rich space to share and search data just as Communication administrations like free email or substance arrangement for the clients. (Rajalakshmi and Wahidabanu 2011) has arranged the Info-Ca-Sh dynamic web content information entry for data trade of information among personnel and understudies. The information gateway Info-Ca-Sh centers

Published

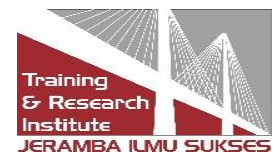


International Journal of information Systems and Informatics

p-ISSN xxxx-xxxx, e-ISSN: $x x x x-x x x x$

Vol. 1, No.1, September 2020

around the improvement in information coordinated effort, codification, and interpersonal organization investigation of higher instructive Institutions. (Rajalakshmi and Wahidabanu 2011) analyzes how Chinese understudies use Web 2.0 innovations for Personal information the executives and distinguishes existing issues in PKM applications. Creator likewise talked about the utilization of wiki or blog to share or move information. (Suradi and Subramaniam 2011) has talked about the sending of K-Portal by utilizing open source instruments JOOMLA, PHP programming language, MySql as database and Apache Tomcat as a web server. The design is to impetus focal point of information data and empowers information sharing society among scholastic staff, inside UNISEL by utilizing K-Portal.

\section{Research Method}

ICT Tools and Resources in Higher Education:

From the Related Work talked about above, it is seen that IM utilizes ICT apparatuses in advanced education for powerful exchange and sharing of information. ICT instruments are sued for correspondence, cooperation, and systems administration usefulness to help information catch, stockpiling, structure and circulation.

Table 1. ICT Tools in Higher Education

\begin{tabular}{|l|l|}
\hline ICT Tools & Authors, Year \\
\hline JANET network & Jennifer Rowley (2000, 2006) \\
\hline Web based Portal, Lotus Notes & $\begin{array}{l}\text { Jillinda J. Kidwell, Karen M. Vander Linde, } \\
\text { Sandra L. Johnson (2001) }\end{array}$ \\
\hline National digital repository by IGNOU & $\begin{array}{l}\text { Saxena Anurag, Khare, Pankaj, and Misra, } \\
\text { R.P. (2003) }\end{array}$ \\
\hline $\begin{array}{l}\text { Web Portal, data warehouses, data mining, and virtual } \\
\text { reality modelling }\end{array}$ & John H. Milam (2004) \\
\hline K-Share web based knowledge sharing tool & Rathinavelu et al(2004) \\
\hline Use of Blogs & Jeremy B Williams, Joanne Jacobs (2004) \\
\hline $\begin{array}{l}\text { Gweb e-KM solution software on Lotus Domino } \\
\text { System }\end{array}$ & Yaying Mary (2005) \\
\hline
\end{tabular}

Published

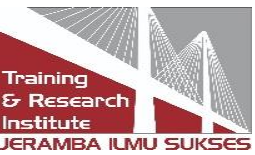




\section{International Journal of information Systems and Informatics}

p-ISSN $x x x x$ - xxxx , e-ISSN: $x x x x-x x x x$

Vol. 1, No.1, September 2020

\begin{tabular}{|c|c|}
\hline $\begin{array}{l}\text { Personal and mental maps , virtual } \\
\text { Blogs } \\
\text { communities }\end{array}$ & $\begin{array}{l}\text { Jonice Oliveira, Jano M. de Souza, Rodrigo } \\
\text { Miranda, Sérgio Rodrigues [2005] }\end{array}$ \\
\hline Software EDULOGIC & $\begin{array}{l}\text { Alok Sharma, Harvinder Saini, Raviteja } \\
\text { Tiruvury[2007]. }\end{array}$ \\
\hline University Research Web-Based Knowledge Portal & Nory B. Jones, Darylyne Provost [2007] \\
\hline $\begin{array}{l}\text { HELP CETL - Communication and Information } \\
\text { Sharing Tool. }\end{array}$ & $\begin{array}{l}\text { Neil Witt, Anne McDermott, Mike Peters and } \\
\text { Mark Stone [2007] }\end{array}$ \\
\hline $\begin{array}{l}\text { Implementation of KM practices in Thailand's Higher } \\
\text { Education development by using ICT tools }\end{array}$ & $\begin{array}{l}\text { Prayong Thitithananon, Tasapong } \\
\text { Klaewthanong, Ubon Ratchathani (2007). }\end{array}$ \\
\hline $\begin{array}{l}\text { K Portal, database } \quad \text { server, search engine, } \\
\text { videoconferencing, discussion room }\end{array}$ & Ruslai Abdullah, (2007) \\
\hline Use of Wiki & Noa Aharony[2008] \\
\hline $\begin{array}{l}\text { Web } 2.0 \text { tools like Dropbox, Google Docs, } \\
\text { Spreadsheets and Mindmeister, wikis, GoogleApps } \\
\text { etc. }\end{array}$ & $\begin{array}{l}\text { Thomas Bebensee, Remko Helms and Marco } \\
\text { Spruit [2009] }\end{array}$ \\
\hline Web portal GNOWSYS & $\begin{array}{l}\text { Meena Kharatmal, Sandhya R., Nagarjuna G. } \\
\text { [2009] }\end{array}$ \\
\hline web 2.0 technology, web based portal, SMS, PDA, & Frank Nyame-Asiamah[2009] \\
\hline Web Portal & $\begin{array}{l}\text { Marjan Mansourvar, Norizan Mohd Yasin } \\
(2010)\end{array}$ \\
\hline $\begin{array}{l}\text { Info-Ca-Sh dynamic web content knowledge portal, } \\
\text { use of Blog and Twitter as tacit codification tools. }\end{array}$ & S.Rajlakshmi et.al. (2011) \\
\hline Web 2.0 Technology like wiki or blog & Xiang Liu (2011) \\
\hline $\begin{array}{l}\text { K-Portal, open source tools JOOMLA, PHP } \\
\text { programming language, MySql as database and } \\
\text { Apache Tomcat as a web server. }\end{array}$ & $\begin{array}{l}\text { Nur Razia Mohd Suradi, Hema } \\
\text { Subramaniam(2011) }\end{array}$ \\
\hline
\end{tabular}

Published

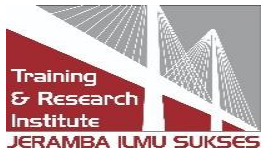


International Journal of information Systems and Informatics

p-ISSN $x x x x-x x x x$, e-ISSN: $x x x x-x x x x$

Vol. 1, No.1, September 2020

\section{Findings and Discussion}

From the above table unmistakably to encourage increasingly expressive trading, sharing and spread of information and its administration, viable usage of information the board in advanced education is required. Schools and colleges have critical chances to apply information the executive's practices to help all aspects of their central goal. Great ICT framework is an unavoidable precondition for any fruitful presentation of IM approaches and strategies into advanced education. Regularly utilized IM instruments/advancements are Information and Communication Technology (ICT), Knowledge-Based Systems, Data Mining, Artificial Intelligence, Modeling, together with their applications on various research and issue areas. Resources and understudies in advanced education utilize ICT apparatuses, for example, PPT, LCD, General application programming, Internet, Intranet, CDs, DVDs and so forth to disperse and share their insight. In advanced education foundations, online application instruments used are Web Portal, Search Engines, Blogs, Wiki, Chat meeting and Discussion gatherings to share and produce information. ICT Tools and assets permit, omnipresent and multi channel access and conveyance of data, putting away and recovery of information/data, improvement of interoperability between frameworks, correspondence and trade of data in PC bolstered cooperative learning. Likewise the methodologies like information mining and information disclosure open new roads in advanced education for understanding the marvel and all the more critically in contriving strategies which will guarantee better instructing and learning process. (Kidwell, Vander Linde et al. 2000) affirmed that if information the executives devices are applied viably, they could bring about better dynamic capacities, diminished item advancement process duration (for instance, educational program improvement and research), improved scholarly and managerial administrations, and decreased expenses.

\section{Conclusion}

To confront the opposition and decreasing inventory of understudies, universities can just make due by making center abilities in the present condition. Alongside the innovation to prevail in the use of information the executives in advanced education, it is fundamental that, the mentality of individuals should transform from my insight as far as anyone is concerned. We should attempt to make the institutional data base open to all the individuals from the establishment. In the event that we can create coordinated effort and information sharing, it will be an extraordinary boo for organizations. The prerequisite is legitimate participation, coordination and cooperation among the workers in the higher organization.

\section{Reference}

Published

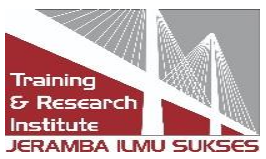


International Journal of information Systems and Informatics

p-ISSN $x x x x$ - xxxx, e-ISSN: $x x x x-x x x x$

Vol. 1, No.1, September 2020

Abdullah, R., et al. (2007). "Developing Knowledge Management System for Public Higher Learning in Collaborative Environment." International Journal of Computer Science and Network Security 7(7): 331-341.

Aharony, N. (2008). The use of Wiki in a knowledge management academic course: A qualitative investigation. Proceedings of the Chais conference on instructional technologies research.

Bebensee, T., et al. (2010). Exploring Web 2.0 applications as a mean of bolstering up knowledge management. ECKM2010-Proceedings of the 11th European Conference on Knowledge Management: ECKM2010, Academic Conferences Limited.

Davenport, T. H. and L. Prusak (1998). Working knowledge: How organizations manage what they know, Harvard Business Press.

Elias, M. A. and M. G. Hassan (2004). Knowledge Management Upper Saddler River, New Jersey: Pearson Education, Inc.

Jones, N. B., et al. (2006). "Developing a university research web-based knowledge portal." International Journal of Knowledge and Learning 2(1-2): 106-118.

Khare, P., et al. (2003). "Knowledge discoveries on performance of IGNOU science graduates through data mining." Indian Journal of Open Learning 12(1/2): 29-46.

Kidwell, J. J., et al. (2000). "Applying corporate knowledge management practices in higher education." Educause quarterly 23(4): 28-33.

Mansourvar, M. and N. M. Yasin (2010). "Web portal as a knowledge management system in the universities." World Academy of Science, Engineering and Technology 70(1): 968974.

Meena Kharatmal, S. R. and G. Nagarjuna (2005). "Information and Knowledge Management Using GNOWSYS." Recent Advances in Information Technology: 160.

Milam Jr, J. H. (2001). "Knowledge Management for Higher Education. ERIC Digest."

Nyame-Asiamah, F. (2009). "Exploiting tacit knowledge through knowledge management technologies."

Oliveira, J., et al. (2005). "GCC: An environment for knowledge management in scientific research and higher education centres." Proceedings of I-KNOW'05: 633-640.

Petrides, L. A. and T. R. Nodine (2003). "Knowledge management in education: defining the landscape."

Rajalakshmi, S. and R. Wahidabanu (2011). "Sharing and Capturing Tacit Knowledge in Higher Education--The Info-Ca-SH." International Journal of Computer Theory and

Published

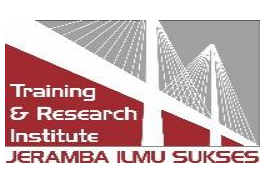


Engineering 3(3): 365.

Renner, J. (2004). "EDU-COM 2004 International conference: new challenges for sustainability and growth in higher education."

Rowley, J. (2000). "Is higher education ready for knowledge management?" International journal of educational management.

Sharma, A., et al. (2007). "EDULOGIC+-Knowledge Management through Data Analysis in Education." World Academy of Science, Engineering and Technology 25(2007): 239-243.

Suradi, N. R. M. and H. Subramaniam (2011). "Knowledge management: An implementation of K-Portal In fiit, unisel." Journal of Knowledge Management Practice 12(1).

Thitithananon, P., et al. (2007). "Knowledge management is a perfect education development tool: Is Thailand's higher education really ready to embrace IT?" Journal of Knowledge Management Practice 8(2): 1-5.

Williams, J. B. and J. Jacobs (2004). "Exploring the use of blogs as learning spaces in the higher education sector." Australasian journal of educational technology 20(2).

Yeh, Y. M. C. (2005). "The Implementation of Knowledge Management System in Taiwans Higher Education." Journal of College Teaching \& Learning (TLC) 2(9).

\section{Copyrights}

Copyright for this article is retained by the author(s), with first publication rights granted to the journal.

This is an open-access article distributed under the terms and conditions of the Creative Commons Attribution license (http://creativecommons.org/licenses/by/4.0/) 